\title{
SOCIO-PSYCHO ANALYSIS IN ZORA NEALE HURSTON'S THEIR EYES WERE WATCHING GOD
}

\section{P. V. RAJLAKSHMI}

Assistant Professor, Department of English, Kongu Arts and Science College, Autonomous, Erode, Tamil Nadu, India

Literature is a reflection of human life. The interrelation between the human mind and the society reflect in the literature, if not consciously, at least unconsciously. Authors registered their traces in their writing, which are hidden within their inner heart. For instance, Zora Neale Hurston's Their Eyes Were Watching God (1937), is a novel which registers the unconscious impression of African American struggling of Hurston's inner heart, through the characterization of Janie Crawford, the protagonist of the novel. By taking the lessons from Janie, the present age women should come out of their sophistication zone, to get the determination and tolerance for handling own life challenges, rather than emotionally inferior.

KEYWORDS: Society, Determination, Individuality, Adjustment, Feminine Identity, Unconscious Expression, Horizon \& Inner Heart
\end{abstract}

Received: Aug 18, 2017; Accepted: Sep 04, 2017; Published: Sep 13, 2017; Paper Id.: IJELOCT20174

\section{INTRODUCTION}

Human beings are social mules. Social set up changes from age to age, place to place and in all kinds of human circumstances. Regarding their own history, men recorded the historic documentation, through the literary influences. So, people started writing. The art of writing provides meaning for human existence, through the exploration of knowledge progression. The purpose of writing in older ages is to document the historical evidences, with artistic composition for teaching their society discipline and traditional values, to the descendants; it cannot be destructed, even by the invaders. If it is recorded in any other scriptures, it might be devasted or vanquished. Thus, the pioneers of literature established the strongest roots, for their descendants through unconscious knowledge and pride. In Thought and Tradition in Contemporary World Literature Prof. S. D. Sargar says:

Literature is an artistic expression of the relationship between the thoughts and feelings of the human mind and

The social conditions surrounding it, when some new stream of thoughts and feelings begins to flow

Continuously, with its uniqueness, quality and quantity, it becomes a small stream of literary work flowing

Towards the great ocean of literature. (184)

The author emphasizes a literary art to compose and to portray reality, in the form of simplest narration and events with the construction in philosophy. According to a writer, reality lays on his consciousness and his imaginative world. The world consists with his/her personal experiences and fantasies. But, it is excluded from the existing reality. The existing reality is huge, unstable, chaotic, confusable and uncertainties. By using the raw 
implementations, ideas and thoughts, the author constructs the plot, characters, intricacies and cohesive situations.

A literary art is a medium of communication. It connects the society and a mind state of an individual. Through the words of narrator, the author projects this world in a different point of view, rather than himself. It is an unconscious autobiography of the writer. It helps readers for expressing his/her unconscious self, which existed at the inner-self, along the coupled contemporary social experiences. Sometimes, it serves as a reflection of rude realities of the age. In African American novels, it could be obviously witnessed, all the serious historical evidences of that society got barely exposed.

The moral values of the particular community may vary according to the people and the changing trends. In historical perspective, an age reflects the traces of its previous age and the key factor, to its following age. Men belonging to a particular age need to accommodate with the present age. He should navigate life to all of the present scenarios. All these adjustments have expected from a man, to express himself as a perfect social mule of that particular age. Amidst these, he is deviated from his own self in all kinds of adjustments. For the sake of the perfection, he sacrifices and searches himself African American people have reached their remarkable height of social status, by searching their identity through the powerful medium of literature. They have created a special phrase for their identity, in the world to identify themselves as 'Mulattos'.

In African American literature, each and every writer express their struggle and suffering with autobiographical hints. African American literature is not just the reflection of Black literary intelligence, but it stands as documentary evidence too. It flows purely out of the own experiences. According to African American people, they registered their mind that, they displaced their knowledge progression, behavioral activities and natural innocence, ignorance, and mentalslavery led them to feel inferior to express in public among the White dominance and cunnings. Their explorations interpreted the adequate information's of African American struggling.

African American literary wisdom surfaced with the world, during the times of 'Harlem Renaissance' correspondingly, the formative years of the twentieth century. African American literature dumps with the depictions of harsh realities, about the African American slave life prominently. The signs and typical truths are brought to know the American minds. African Americans searched and transformed their thirst into the decedents' mind and to sow the seeds on finding self, through the medium of writing novels. After obtaining the independence, African Americans had provided education to their children. Some of the Black writers started to write novels, to create awareness among the Whites, rather than their own community, about their identity crisis, how they were struggling for their basic needs

African American themes deal with the racial issues, double-consciousness, and innocence of African American people. Through the writings, they had attempted many indirect attacks on Whites, not in sarcastic manner, but in euphemistic terms. After reading the novels of African American literature, many of the Whites had realized their inhumanity. So, there were so many historic incidents occurred not only African American social life, but also in literary society. The Harlem Renaissance viewed, in spite of its physical presence, its literary infrastructure, the nature of Harlem and its relation to the Renaissance are very complex.

The Harlem Renaissance includes and heightens racial consciousness. All the African American novels projected only in a masculine way of interpretations. Most of the writing in African American literature, describes the pathetic conditions of the people. In feminist writings, they also exhibit concern on the self-identity, not only as a woman, but also as an African American. Too much of suppression has made them turn into a search for narcissism. In this movement, the 
authors commemorated, such as LeRoi James (Amiri Bakara) and Larry Neal, have attempted to promote the literary forms, according to the typical African American vernacular tradition. The African American literary texts construct the bridge between the writer and the reader of African American.

Women develop a folk culture and oral tradition, to support each other in a sexist community. They challenged the dominant sexist community with a folk culture, that is based on the African American female experiences in the society. They create language, symbols and modes of expression that reflects the life of an African American woman. Unfortunately, not all African American women access to literary expression, which meant that the folk culture lived through memories, and storytelling.

African American female writers like Alice Walker turn out their own traditions, searching for footprints of African American women. Alice Walker's research resulted in a collection of essays, In Search of Our Mothers Garden. Even though Zora Neale Hurston's writings, condemned as worthless, Zora's efficiency is taken out by Alice Walker. In present time, she considers as a precious African American female writer (rather than feminist) she was always viewed the way but not among critics. Her most popular novel Their Eyes Were, Watching God was published in 1937, but did not gain popularity until Alice Walker rediscovered Zora Neale Hurston in 1970's. Walker introduces Zora to the world in her essay In Search of Our Mothers Garden, as:

Makes gender politics central to the representation of Black experience in America, as it charts the coming voice of its female protagonist. In this 'speakerly' text, which asserts the creative potential of oral traditions, Hurston, a trained anthropologist and folklorist, use the familiarity with a range of lack vernacular expressive forms, such as sermons, spirituals and folk tales, to develop a style of writing to which Alice Walker and Toni Morrison, amongst others, acknowledge a debt (257).

A writer herself, Walker discovers the writing of Zora Neale Hurston, while working in discovery, Hurston had become a great influence on the Walker's later work. In the words of Freeman, "though separated by place and time, these two Black women writers, inevitably it seems, were drawn together, and Zora Hurston became an important influence in Alice Walker's life" (451). Walker has confessed the best book she had ever read was Their Eyes Were Watching God.

Hurston's attempt to present the fullness of Black people, but she was misjudged and misunderstood by her contemporary people. Hurston was harshly criticized for presenting African American people without a purpose, talking and laughing, not doing anything, which, according to critics portray the Black people in a negative way, and a laughing matter to White people. Hurston's Their Eyes Were Watching God offers in reality a complex representation of Black culture where she is able to show the diversity of Black people.

Zora's Their Eyes Were Watching God, was criticized by both White and Black men. Hurston neglects the racial essentiality rather than humanity. The only difference between the races, according to Hurston was the color of their skin. But Hurston had strong connections to her southern roots, which is evident in Their Eyes Were Watching God, where she celebrates and documents African American culture, though the novel addresses the themes of romance, community rituals, race relations, gender roles as well as women's sexuality and identity. She celebrates the complexities of women, which Lester claims that Black women were denied historically, political and literary.

Hurston is a more productive writer than any of her African-American predecessors. In the beginning of her writing career, Zora Neale Hurston, as an African American woman forced the oscillations to express herself as a woman 
and to express herself as a writer because that was male-dominated profession and according to American literary circle, might never bring proper response for female voice. Hurston had come to understand, that Martza had referred, "the conflict between the individual's desire, to explore herself and the community's need to stride this to achieve order and stability" (43-54). Like Janie, Hurston also had faced too many obstacles, to find out her self-identity among the maleoriented literary world. The suppressions gain not only in the phase of Whites' reticulation, but also from her own community readers. The emphasis of Janie's character had overcome the social and personal obstacles. This is a portrayal of the uniqueness in Janie, who relates to Hurston's socio-psychological phase.

The introductory scene of Janie at Eatonville is the resemblance of nativity of African American people. Janie had brought up as a blooming bud, that has never been touched by any worldly dusts at her native town. It has represented the African American people's life on their native land. They were very happy without any struggles in their native land. They have migrated towards America for improving their financial crisis. African people's nature is that they were incomparable in physical strength, but very innocent in thinking. They were not aware of that they would never be treated as human beings. Mentally they had been made up their mind, that White people are their soul masters. This is the accurate description of Janie's characterization.

Hurston's determination is exactly transformed through the character of Janie, at last. Janie had introduced as a new flower that blossomed now. She had never touched by any race and gender basements under the preventive care of her grandmother, Nanny. The opening chapter of the novel was depicting the tenderness of Janie with the corresponding beauty of nature, during her teenage. But her life had entered into the trap of marriages. First marriage had taught her the lesson that love had never happened by anything, but the unification of two hearts. So she had left. She got alienation with disappointed. She has found a single chance to express herself. Apart from the sensual pleasures, Janie has felt only loneliness. When she had eloped with Joe Starks, Janie was thinking herself as she had upgraded to the numeric steps at her maturity.

Joe Starks has the motivation of utilizing the hard work and tenderness of Janie, which she had believed as the determination and maturity. She had hidden all her pains only for the sake of protecting her only relationship in the world that is her husband Jody, after the death of Nanny. Janie learns that Jody's exertion of power only stifles her. But just before Jody's death. Janie's repressed power finally breaks through in a stream of verbal relation. Her cruel invective at the dying, Jody measures the depth of his suppression of Janie's inner self. Having begun to find her voice, Janie blows through social trivia to express herself fully. Finally, the expression has formed the medium of noiselessness.

The representation of Janie's silence is looking forward to the liberation and identity. Janie had lost the thing for what is railed from Logan. According to Zora, all the tortures of Joe Starks have given to Janie had associated with the White masters who have abused their Black slaves. Janie obeyed without any questions, that all the orders had been passed by her master Joe - who has shown the attitude like Whites - as Black slaves have done with their duties for White masters, even though they have suffered. Similarly, Janie burst out to Starks when he had fallen into the dead bed and, even after his death. This shows the achievement of Hurston's power of executing skills.

Tea Cake functions as the catalyst that helps drive Janie toward her goals. Like all of the other men in Janie's life, he plays only a supporting role. Janie's blissful marriage with Tea Cake lasts for about two years, then a storm hits like the Everglades, and God takes his glance away. During the raging storm, God seems to be speaking Janie and Tea Cake wait for God to make His move, and when obliteration appears looming, Janie and Tea Cake strike out for higher ground. In a 
heroic struggle against the raw power of nature, they make it, but not before Tea Cake are bitten by a rabid dog in an effort to save Janie. Several weeks later, Janie is forced to kill the man she loves.

The role of Tea Cake is viewed as the social revolutions, that had occurred against the Americans, especially it had the embodiment of the Harlem Renaissance. There are so many social changes, that had been created to find the identity of Black slaves and find a voice, that could be raised against their White Masters' through the arts including literature. The displacement of Janie from Eatonville to Tea Cake's town is the resemblance of Harlem Movement - Black slaves had moved towards Harlem for liberation. Before his arrival, Janie has already begun to find her own identity, as is demonstrated when she finally stands up to Jody. As we see at the end of the over, after Tea Cake's death. Janie remains strong and hopeful; therefore, it's fair to say that Janie is not dependent on Tea Cake. Nevertheless, he does play a crucial role in her development. Instead of that, he has brought remarkable displacements.

The novel ends when it began, with the perceptual world of the narrator, who releases it from the temporal world. In the way, Janie and Tea Cake achieve a greater freedom in the world tomorrow and Janie triumphs over her critics, the negative community of gossiping women, to whom the reader is introduced in the book's opening scene that draws the sermon together.

Hurston decently and indirectly indicated the African American people, to be a human beings apart from the racial and gender issues. This is the determination of Janie's self-identity, because Janie had not only projected as an individual, but the collection of voice that emphasized for entire African American woman community. Though Tea Cake plays a vital role in Janie's development, he is not an indispensable part of her life, a crucial truth that revealed when Janie shoots him. He plays a role in her life, helping her to better understand herself. By teaching her how to shoot a gun, ironically, he provides her with the tools that ultimately kill him for happiness, but to help her find happiness and security within herself. Through, the character of Janie, she had framed the principles for a woman, how to lead a satisfied life to be a woman.

The rules that have been sketched by Zora, helped to lead an upgraded lifestyle for each African American woman. Thus, she had also proved her individuality. The determination of Janie stands for the perseverance of the selfidentity. Though, she has made lots of adjustments and compromises, she has never given up. Lastly, she felt proud of her feminist attitude. She is narcissistic about her feminine identity. She is strong enough to face all her disappointments. But, the language of her mind repeated the same thing, that everything will be a passing cloud. There is no projection of Janie's fallen or depressed thoughts, in the novel. She had overcome all the obstacles, with her grim determination and selfconfidence. Hurston ends Their Eyes Were Watching God, with the following words:

The kiss of his (Tea Cake) memory made pictures of love and light against the wall. Here was the peace. She pulled in her horizon like a great fishnet. Pulled it from around the waist of the world and draped it over her shoulder. So much of life in its meshes! She called in her soul to come and see (184).

Janie's last movement toward the horizon, represents the struggle the corporate black community has to come to terms with the oppressor's negation of its representation. Out of this negation, the mystic consciousness seeks a new beginning in the future by imagining an original beginning. The social implications of the religious experience, enable the oppressed community to dehistorize the oppressor's hegemonic dominance. Metaphorical phrase Their Eyes Were Watching God means the creation of a new form of humanity - one that is no longer based on the master - slave dialectic. She exercises autonomy in making her world through language. 
In Their Eyes Were Watching God, she has proved her multiple dimensional inner self. She has known the euphemistic projection of women's abusements. She has the wisdom of satirizing the social evils that have posed to African American people. She has the incomparable courage to attack the mistakes have been committed by her own community people, under the shadow of searching herself and social identity.

Janie's uniqueness are associated with Zora and the novel Their Eyes Were Watching God, under the title of 'identity crises' through the protagonist, Janie Crawford, as an exact species of Zora Neale Hurston. In spite of, diverged emphasize of ideas in the novel Their Eyes Were Watching God Janie, the protagonist has attained her goal of cultural independence as a Black woman, Janie's incessant struggles lead her to reach self-identity, which served an inspiration to all women. Janie's conception of death reveals the manner in which language itself is alive, with the history and the historical to the leads of the emergence of an African American culture in a Eurocentric world.

In the pulling fishnet around her shoulders, Janie asserts the bleakness. An optimist and romantic, Janie seeks a large space for herself and she likes story; her quest involves the women's timeless search for freedom and self-identity. Janie, in her movement to stick the horizon, that is in the successful execution of her performance via the sermon, if transformed from blues figure to clairvoyant. In doing so, she both achieves self-identity and assumes a communal role traditionally reserved for males. She appreciates the troops for evocation and reunion in order to insert her voice, into history. The logical conclusion to Janie's female-centered discourse can be applied to the contemporary women in the world.

People in contemporary social status, have to be more patient like Janie. The present age people, particularly, women find so many opportunities to flourish their life in contemporary circumstances. But, they have lost their life due to lack of patience and do never possess the stuff to tackle the problems. They have preferred to escape from the trouble, which they have predicted as a permanent solution. Life has to move on whatever happens. Rather than struggling with mental problems, they can attempt to understand causes and circumstances. The self understanding can only give clarity to the mind.

\section{REFERENCES}

1. Freeman, Alma. S. “Zora Neale Hurtson and Alice Walker: A Spiritual Kinship” Analysis and Assessment, 1980-1994, Ed. Cary D. Wintz. New York and London: Garland Publishing, 1996. Print.

2. Hurston, Zora Neale. Their Eyes Were Watching God. New York: Perennial, 1999. Print.

3. Matza, Diane. “Zora Neale Hurtson's Their Eyes Were Watching God and Toni Morrison's Sula: A Comparison”. MELUS 12.3 (1985). Print.

4. Sagar, S.D. "African American and Dalit Autobiography”. Thought and Tradition in Contemporary World Literature, Ed. Dr. Ram Sharma and Dr. Gujan Agarwal. Jaipur: Yking Books, 2014. Print.

5. Walker, Alice. In Search of Our Mothers' Gardens: Women's Prose. Orlando: Harcourt, 2004, Print. 